\title{
Participatory democracy for our time
}

BOOK TITLE:

Are South Africans free?

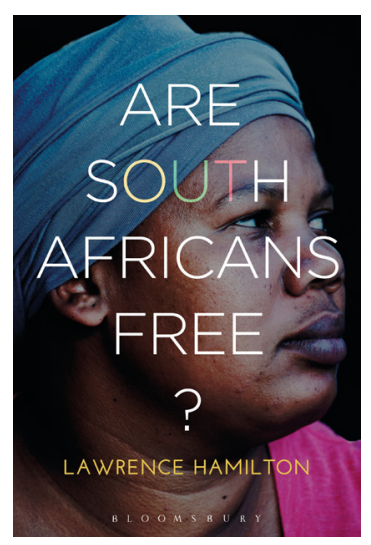

AUTHOR:

Lawrence Hamilton

ISBN:

9781472534613 (softcover)

\section{PUBLISHER:}

Bloomsbury, London; GBP16.99

\section{PUBLISHED:}

2014

\section{REVIEWER:}

Anthony Egan

\section{EMAIL:}

anthegan2@gmail.com

\section{AFFILIATION:}

Steve Biko Centre for Bioethics, University of the Witwatersrand, Johannesburg, South Africa

\section{POSTAL ADDRESS:}

Steve Biko Centre for

Bioethics, University of the Witwatersrand, Private Bag 3 , Johannesburg 2050, South Africa

\section{HOW TO CITE:}

\section{Egan A. Participatory} democracy for our time. S Afr J Sci. 2016;112(1/2), Art. \#a0137, 2 pages. http://dx.doi. org/10.17159/sajs.2016/a0137

(C) 2016. The Author(s). Published under a Creative Commons Attribution Licence.
As I read University of the Witwatersrand's political philosopher Lawrence Hamilton's challenging new book, I could not but recall another work written in different historical circumstances but with a similar sense of urgency - The Eye of the Needle by Rick Turner' ${ }^{1}$. Turner's book was first published in 1972 as a contribution to, indeed a radical critique of, the Christian Institute and SPRO-CAS (Study Project for Christianity in Apartheid Society) attempt to imagine a post-apartheid society. Although Turner had worked with SPRO-CAS, he was critical of its overtly liberal democratic conclusions, which he felt failed to understand the prerequisites for a new democracy. Given the nature of South African society then, Turner saw the only moral and practical solution in participatory democracy and socialism.

While not necessarily socialist as Turner was in 1972, in so many ways Hamilton is doing the same for South African democracy today - challenging our presuppositions, calling us out of our temptation to cosy consensus or despair. He starts with a shocking suggestion: the idea of freedom, enshrined in the Constitution and Bill of Rights, has simply not been realised more than 20 years after the transition to democracy. He argues:

\section{If freedom is conceived of in realistic, substantive and practically meaningful terms as 'freedom as power through political representation', we have no option but to conclude that South Africans are not yet free... (p.124),}

because in social, economic and political domains South Africans lack power. This provocative claim, which may seem to the complacent to be counterintuitive, is based on what he sees as the elite compromise (mainly between the African National Congress (ANC), the National Party and local and international economic interests) that failed to empower - to free - South African citizens (a similar view can be found in Habib²).

Two key elements of the transition 'pact' highlight this claim. The first can be summed up as the electoral system of party list-based proportional representation (PR), which placed too much power into the hands of parties and their leaderships. Although it was argued in the 1990s that the PR system was fair (particularly to minority parties who might otherwise vanish under a Westminster 'first past the post' system) and easy to manage, even its proponents agree that the party list PR model has disadvantages. ${ }^{3}$ Party list PR is customarily used in small countries with fairly homogenous populations, not a good start for South Africa! But the most notable problem is that by voting for a party, citizens have limited ability to directly choose representatives as such; parties choose candidates and voters choose the party. The result is that voters have little say over who specifically goes to parliament and who stays in parliament. They cannot express disapproval with individual parliamentarians without voting against a party they might support. The party is all, the citizen is vote fodder.

The problem can be further exacerbated by situations in which said parties are riven with factionalism, authoritarianism or corruption, often resulting in direct manipulations of organs of the state (including those that exist to protect constitutionally guaranteed freedoms), and in situations in which one party may be dominant. Sadly, all these features are to be found to varying degrees within the ruling ANC. And many (including some from within the ruling party) see widespread manipulation within organs guaranteeing constitutional freedom. We might even say that we see a feature Southall ${ }^{4}$ noted in many former liberation movements in government: the conflation of ruling party with government, state and nation.

The second problem with 1994 was the decision to embrace the globally dominant neo-liberal model of economy, which - despite affirmative action and black economic empowerment - substantially preserved the old order's economic status quo and weakened the basis for economic and social development. This decision was partly the result of a hope that by going with what was then considered the 'consensus', foreign investment would revive what was by the early 1990s a severely weakened economy. This has failed in the long term to deliver the promised goods. In addition, as Hamilton and many others note, the neo-liberal 'consensus' has had a very mixed history in delivering prosperity in developing economies (I am being generous in this observation) and is by no means the sole model for economic development even under a capitalist system. During the 1960s, for example, many Asian economies that became prosperous used a far more 'statist' and interventionist approach to development. One might add, as Cambridge economist Ha-Joon Chang has observed, that some of the most powerful free market economies (like the USA, China and Russia) have either risen to prosperity through capitalist forms of statism, or have continued to combine statism and neo-liberalism. ${ }^{5,6}$

To this arguably theoretical objection, Hamilton poses the important question: How has the 1994 decision affected South Africans' economic quality of life? Despite the clear emergence of a new black middle class, the majority of South Africans remain poor, with low levels of human development, particularly in what is considered a middle-income country. The reason for this situation is growing inequality, making us one of the most unequal societies in the world.

Moving beyond the specific politics of transition, Hamilton presents a philosophical account of why he embraces a definition of freedom as power. Freedom as power does not divorce liberty from the notions of power and representation. This is important because what he calls the liberal or republican model can easily become an abstraction rather than an expression of something concrete. Freedom as power does not reduce freedom merely to absence of external impediments, self-determination or absence of citizenship. It is not enough to be free from unjust constraint, from being the subject of a tyrant. Nor is it enough, Hamilton seems to be saying if I read him correctly, to have the right to vote every few years. Real freedom must entail active agency, participation in society and individual and communal development. 
In short, Hamilton is advocating a form of what Turner called, four decades ago, participatory democracy, where individuals actively and directly choose who shall represent them, and when needed remove from office those who fail to deliver. Similarly, such participation must entail full and meaningful participation in an economic life. Under this account one can see why Hamilton presents the thesis that most South Africans are not yet free. The PR electoral system makes representation difficult and an economy that still excludes many from the possibility of fulfilment of their potential disempowers those who are poor.

Like Turner, Hamilton not only diagnoses the malaise but proposes certain remedies. He recommends a shift away from the party list PR system towards a mixed model, in which citizens directly elect persons as representatives and a party. The model that comes to mind (and to which he refers) is that of Germany, where parliament is constituted of both representatives chosen from a party list and directly elected members. It is an effective model that combines the advantages of PR and Westminster and reduces the disadvantages of both. (He also alludes in passing to Ireland, which is a somewhat different, more complicated system. Personally, having looked at both systems, I think Germany's model better meets the criterion of simplicity.) Hamilton also sees the need for the restoration of parliamentary sovereignty: in effect this means the reduction of one party dominance. He also, in a turn again reminiscent of Turner, sees the need for District Assemblies of citizens - participatory bodies marked by diversity that address policy issues. In a move that some may see as iconoclastic, he advocates plebiscitebased constitutional and policy revision. Similarly, he suggests that the demand for greater equality - a prerequisite of real freedom - may require revisiting the economic models and policies currently in place, because they simply do not work.

As I have already noted, this book, like Turner's Eye of the Needle, is challenging. When I first read Turner in the mid-1980s as an undergraduate, I was struck by how much of it was a product of its time, with an analysis of South Africa both prescient and problematic. The problem with it was that, with hindsight, some of its proposals were simply wrong: homeland leaders by the 1980s were no longer potential allies of the struggle, the homelands were no longer potential zones of freedom. Yet Turner's foundational point - the need for participatory democracy and the creation of effective grassroots organisations, alliances between groups sharing much in common, etc. - was right. I get a similar sense when I read this book.

From a historian's perspective, I do not share what I think is Hamilton's reading of the ruling party: a great party that has somehow recently lost its way and needs to find it again. Recent revisionist history suggests a very 'mixed' view of the ANC: allowing for difficult political circumstances on one hand, author bias and possible exaggeration on the other, Ellis'? proposal of corruption and authoritarianism in the exiled ANC suggests a consistent shadow side to our major (but never sole) movement of liberation, something that might explain its less salubrious side today. The consolidation of the relatively more participatory democratic United
Democratic Front into the ANC during the transition period, with a relative eclipse of the latter in party leadership, might be a more nuanced perspective - which, however, in no way undermines the key points Hamilton makes, particularly his implicit unease with overt rejection of the ANC. Pragmatically, I would argue that the kind of change Hamilton seeks is unlikely to come from other parties, not least because they currently lack a strong power base, nor from the current ANC.

I also wonder whether the kind of effective economic reform, although manifestly necessary, is possible in the short to medium term. More than 20 years later, we may be faced with too few people with both skills and self-motivation to create a successful economy based on what would need to be done: redistribution of resources, creation of new jobs and the building up of enterprises among the poor. A bad education system can barely serve the unequal and unjust economy we have now. To make Hamilton's model work would entail real capacity-building on a massive scale, as well as a new work ethic. Both can be done, but I wonder whether the old and new elites have the will to do it. That said, if it is not done I can foresee more of the same ultimately self-destructive actions (service delivery protests, xenophobic struggles over scarce resources, etc.) that Hamilton rightly sees as a dangerous and mistaken short-term reaction to our highly unequal society.

These caveats (possibly an expression of a certain 'pessimism of the intellect') aside, I thoroughly recommend Lawrence Hamilton's book. If I may hark back one last time to Rick Turner, despite the problems I had with Eye of the Needle back in 1985, his is a book that at the risk of waxing sentimentally, profoundly affected my way of seeing my world at the time. Turner's broad vision, his underlying 'optimism of the will', captured my political and moral imagination. I have read it many times and still find it inspiring. In many respects this is what Lawrence Hamilton also does in this little volume. Faced with so many challenges, it is a tightly argued and passionately articulated call to rethink our society. And to act.

\section{References}

1. Turner R. The eye of the needle: Participatory democracy in South Africa. Johannesburg: SPRO-CAS; 1972.

2. Habib A. South Africa's suspended revolution: Hopes and prospects. Johannesburg: Wits University Press; 2013.

3. Diamond L, Plattner MF, editors. Electoral systems and democracy. Baltimore, MD: Johns Hopkins University Press; 2006. p. 73-134.

4. Southall R. Liberation movements in power: Party and state in southern Africa. Pietermaritzburg: University of KwaZulu-Natal Press; 2013.

5. Chang H-J. Bad Samaritans: The myth of free trade and the secret history of capitalism. London: Bloomsbury; 2008.

6. Chang H-J. 23 Things they don't tell you about capitalism. London: Penguin; 2010.

7. Ellis S. External mission: The ANC in exile, 1960-1990. Johannesburg: Jonathan Ball; 2012. 